\title{
Structural and Functional Analysis of the Human Nuclear Xenobiotic Receptor PXR in Complex with RXRa
}

\author{
Bret D. Wallace, Laurie Betts, Garrick Talmage, Rebecca M. Pollet, Natalie S. Holman, and \\ Matthew R. Redinbo* \\ Departments of Chemistry, Biochemistry and Microbiology, University of North Carolina at Chapel \\ Hill
}

\begin{abstract}
The human nuclear xenobiotic receptor PXR recognizes a range of potentially harmful drugs and endobiotic chemicals, but must complex with the nuclear receptor RXRa to control the expression of numerous drug metabolism genes. To date, the structural basis and functional consequences of this interaction have remained unclear. Here we present $2.8 \AA$ resolution crystal structures of the heterodimeric complex formed between the ligand binding domains (LBDs) of human PXR and RXRa. These structures establish that PXR and RXRa form a heterotetramer unprecedented in the nuclear receptor family of ligand-regulated transcription factors. We further show that both PXR and RXRa bind to the transcriptional coregulator SRC-1 with higher affinity when they are part of the PXR-RXRa heterotetramer complex than they do when each LBD is examined alone. Furthermore, we purify the full-length forms of each receptor from recombinant bacterial expression systems, and characterize their interactions with a range of direct and everted repeat DNA elements. Taken together, these data advance our understanding of PXR, the master regulator of drug metabolism gene expression in humans, in its functional partnership with RXRa.
\end{abstract}

\section{Keywords}

transcription factor; nuclear receptor; DNA; x-ray crystallography; CYP3A4

\section{INTRODUCTION}

The human biotransformation of xenobiotics is conducted by a large array of enzymes classified as being part of Phase I (functionalization), Phase II (conjugation), or Phase III (excretion) drug metabolism $1 ; 2 ; 3 ; 4 ; 5$. These systems are clinically significant because they impact drug efficacy and can lead to drug interactions and toxicity. The nuclear pregnane $x$ receptor (PXR) is a member of the nuclear receptor subfamily 1, group I, member 2 subsection of ligand-dependent transcriptional factors $6 ; 7 ; 8$. It is a master regulator of the expression of genes involved in xenobiotic and endobiotic metabolism, although it was originally identified as critical in detecting endogenous pregnanes ${ }^{9}$. Since then, it has subsequently been classified as a central xenobiotic sensor that responds to a number of

\footnotetext{
(C) 2013 Elsevier Ltd. All rights reserved.

*Corresponding Author: Matthew Redinbo, Ph.D., University of North Carolina at Chapel Hill, redinbo@unc.edu. Accession Numbers: The coordinates and structure factors for the Apo-PXR/RXRa LBD complex and SR12813-bound PXR/RXRa LBD complex structures have been submitted to the Protein Data Bank and assigned the identifier 4j5w and 4j5x, respectively.

Publisher's Disclaimer: This is a PDF file of an unedited manuscript that has been accepted for publication. As a service to our customers we are providing this early version of the manuscript. The manuscript will undergo copyediting, typesetting, and review of the resulting proof before it is published in its final citable form. Please note that during the production process errors may be discovered which could affect the content, and all legal disclaimers that apply to the journal pertain.
} 
pharmaceutically relevant compounds and drugs. The promiscuity of PXR's ligand binding has proven to be unique to this nuclear receptor ${ }^{6 ; 10}$, and $\mathrm{x}$-ray crystallographic studies $11 ; 12 ; 13$ reveal a novel insert in the ligand binding domain (LBD), as well as a highly malleable ligand binding pocket. PXR was found to interact with SRC-1 (nuclear receptor coactivator 1) ${ }^{9}$, a member of the p160 family of coactivators that binds in a liganddependent fashion to various nuclear receptors utilizing a Leu- $\mathrm{x}-\mathrm{x}$-Leu-Leu repeat (where $\mathrm{x}=$ any amino acid) ${ }^{14}$. Importantly, like many former orphan nuclear receptors, PXR forms a complex with the retinoid X receptor- $\mathrm{a}(\mathrm{RXRa})$ and binds to DNA response elements to control gene expression ${ }^{6 ; 10}$. RXRa appears to respond to retinoid ligands including 9-cisretinoic acid and all-trans retinoic acid ${ }^{15}$.

A number of PXR LBD crystal structures have been resolved to date in complex with a range of distinct ligands $12 ; 13 ; 16 ; 17 ; 18 ; 19$. Crystal structures of RXRa LBD alone, in liganded complexes, and in heterodimeric complexes with other nuclear receptor LBD's, such as LXR, CAR, PPAR $\gamma$, RAR, and others $20 ; 21 ; 22 ; 23 ; 24$ have also been reported. However, only one crystal structure of a full-length, intact nuclear receptor complex (PPAR $\gamma / \mathrm{RXRa}$ ) has been presented, which revealed a great deal about the orientation of the DNA and DNA-binding domains (DBDs) of the heterodimeric complex relative to the LBDs ${ }^{25}$. In contrast to most nuclear receptors, PXR was shown to form a functionally essential homodimer not seen previously for this superfamily of transcriptional factors ${ }^{26}$. It was established in vitro and cell-based studies that the PXR homodimer interface impacted the recruitment of the steroid receptor coactivator-1 (SRC-1), but did not affect ligand binding, DNA binding or subcellular localization ${ }^{27}$. SRC-1, also termed nuclear receptor coactivator-1 (NCOA1), enhances transcription by serving as a histone acetyltransferase and by recruiting the basal machinery ${ }^{14}$. SRC-1 interacts with nuclear receptors via domains with multiple leucine (L) residues arranged in LxxLL motifs ${ }^{28}$.

To date, the three-dimensional structures of PXR have included only PXR, so it remained unclear whether the presence of RXRa would impact PXR's unique homodimer complex. Further understanding of how PXR regulates xenobiotic metabolism requires a more indepth knowledge of the interactions made between PXR and its binding partner RXRa, and how this nuclear receptor complex interacts with various hormone response elements through their DBD. Thus, we elucidated crystal structures of the PXR/RXRa LBD heterotetramer complex in the presence and absence of PXR ligands. In addition, we conducted in vitro studies to determine SRC-1 coactivator binding affinities for the individual nuclear receptors and for the receptors in complex with one another. Finally, methods for the expression and purification of appreciable quantities of full-length PXR and $\mathrm{RXRa}$ are provided, along with their DNA binding characteristics.

\section{RESULTS}

\section{Crystal Structures of the PXR/RXRa LBD Complex}

Structures of the apo-PXR/RXRa and SR12813-bound PXR/RXRa LBD complexes were determined to $2.8 \AA$ resolution (Table 1). These complexes reveal a heterotetramer in the asymmetric unit composed of two PXR and two RXRa LBD monomers (Figure 1A). The two PXR monomers form a homodimer, which has been seen in previous PXR-only LBD structures, and two RXRa monomers are bound to PXR, one per monomer. Both PXR and $\mathrm{RXRa}$ have been fused at their $\mathrm{C}$-termini to the following region of human steroid receptor coactivator-1 (SRC-1): 678-SSHSSLTERHKILHRLLQEGSPS-700, with the LxxLL motif in bold. In PXR, the region corresponding to 681-698 of hSRC-1 is ordered, and is numbered 443-460; in RXRa, the region corresponding to 686-696 of hSRC-1 is ordered, and is numbered 476-486. The PXR residues 130-140, 178-192, 312-314 are disordered in both structures; in addition, the non-native linker-to-SRC-1 peptide residues 433-440 are 
also disordered. The RXRa LBD residues 246-260 are disordered in the apo-structure, but ordered in the SR12813-bound structure; similar to the PXR LBD, the non-native linker-toSRC-1 residues 458-476 are disordered in RXRa LBD structure. The SR12813-bound LBD complex contains one conformation of the SR 12813 molecule in each PXR ligand binding pocket (Figure 1B). Residues lining the binding pocket located within 4 A of the SR12813 molecule are L206, L209, L240, M243, M246, S257, Q285, F288, W299, Y306, M323, H327, H407, R410, L411, I414, and M425. These residues have been established as common amino acids that surround bound ligands in the PXR LBD ${ }^{29}$. Importantly, the structure confirms the PXR-PXR homodimer interface observed in PXR LBD-only structures resolved to date, formed by the $\beta 1$ strands of each PXR LBD monomer (Figure $1 \mathrm{~A})$. Note that $\beta 1$ is located on a $\sim 50$-residue insert unique to the PXRs relative to other nuclear receptors ${ }^{27}$. Thus, these structures establish that PXR and RXRa form a dimer of PXR-RXRa heterodimers, creating a crystallographically observed heterotetramer not observed previously for members of the nuclear receptor family of transcription factors.

The PXR/RXRa LBD heterodimer interface buries $\sim 1200 \AA^{2}$ total surface area, and is composed of several electrostatic and polar interactions found on the four helices that make up the binding surface (Figure 2). Eleven probable electrostatic interactions $(<4 \AA$ ) were observed: Q409-E434 (PXR residue-RXRa residue), E399-R426, H359-E352, H359-K356, D363-K356, D363-R421, Q366-R421, R360-D359, E367-R421, E367-K417, and K374E401. In addition, six potential polar contacts were observed: S402-R426 (PXR residueRXRa residue), E399-R426, H359-E352, D363-R421, K374-E401, and E367-K417. Furthermore, hydrophobic contacts were observed involving RXRa's L420 and PXR's I371, and M394. Finally, a number of water-mediated (R353-R348 [PXR residue-RXRa residue], R353-S427, R360-K356, D363-E352, D363-R421, R401-R348, and R401-S427), side chain-main chain (K325-D379), and intramolecular interactions (PXR: K332, S350, E378, T398, Q406, and R413; RXRa: T351, S355, N377, K381, R393, E394, K405, and K431) were noted that strengthen the dimer interface. Compared with RXRa heterodimer complexes resolved previously, the interface formed between PXR and RXRa is largely similar. For example, a comparison of the PXR-RXRa binding interface to the CAR-RXRa interface reveals similar electrostatic and polar contacts ${ }^{22 ; 24}$. Furthermore, the RXRa LBDs is located in a similar position in its complexes with the LBDs of PXR, CAR ${ }^{22}$; 24 , PPAR $\gamma^{21}$, LXR $^{23}$ and RAR ${ }^{20}$, but some structural differences are evident (Figure 3). Notably, translations up to $6 \AA$ and rotations up to $29^{\circ}$ are observed between secondary structural elements of RXRa (Figure 4).

\section{SR12813-bound PXR/RXRa versus apo-PXR/RXRa}

An overlay of the unliganded ${ }^{30}$ form of PXR in the PXR/RXRa complex with the SR12813-bound complex reveals that, while the all-atom root-mean-square deviation (r.m.s.d.) is $1.49 \AA$ over 998 atoms, a number of small changes in the secondary structural elements have occurred (Figure 5A). Notable shifts in secondary structural elements of PXR

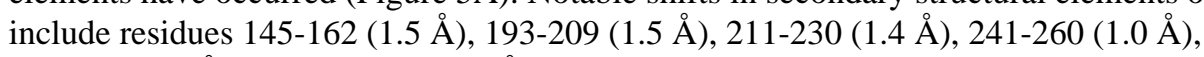
270-289 (1.4 $\AA$ ), and 360-375 (1.4 $\AA$ ) (Figure 5B). Furthermore, shifts are noted in the RXRa LBDs, including 233-242 (1.1 ̊), 264-274 (2.7 ̊), 275-285 (1.5 ̊), 294-318 (1.6

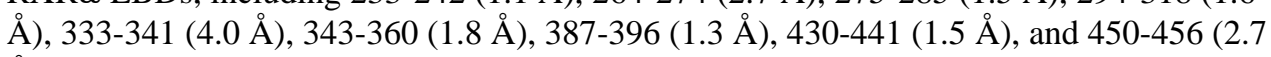
$\AA$ ). The addition of a ligand to PXR facilitates the structural ordering of the entire complex, as evident by the now ordered RXRa residues 246-257. These residues form a helical motif on each end of the complex, leading to a slightly larger unit cell volume (SR12813/Apo volume ratio of 1.13; Figure 5A, Table 1). Interestingly, comparing the same residues from PXR in each complex shows that the addition of the SR12813 molecule compresses the overall structure of the ligand-bound complex relative the apo complex. For example, the length of the SR12813-PXR heterotetramer complex (vertical in Figure 5A) is $\sim 4 \AA$ less 
than the length of the corresponding apo-PXR heterotetramer (apo $\approx 130 \AA \AA$; SR12813 126 $\AA$ ). This observation supports the general belief that the binding of activating ligands serves to stabilize nuclear receptor complexes in a manner similar to the addition of coactivator fragments $11 ; 29$. In the structures presented here, though, the mean thermal displacement parameter (B-factor) for the ligand-bound complex $\left(54 \AA^{2}\right)$ is higher than the same value for the apo complex ( $35 \AA^{2}$ ) (Table 1), while the overall Wilson B-factors on the data show the opposite trend, $37 \AA^{2}$ for ligand bound and $43 \AA^{2}$ for apo (data not shown). This may be a product of the 23 additional residues modeled in the SR12813-bound complex structure.

\section{Nuclear Receptor Oligomerization and Coactivator Binding}

It had been previously shown that the PXR LBD contacts 15 residues of the LxxLL motif of SRC-1 ${ }^{11}$, which is approximately five additional amino acids relative to other NR LBDs crystal structures examined. The structures reported here confirm the previous data, with one turn of a-helix preceding the LxxLL helices of SRC-1 in PXR relative to RXRa (Figure 6A). In both cases, though, the LxxLL motifs of SRC-1 were fused to the C-termini of the LBDs to improve purification yield. We next purified PXR and RXRa LBDs without fused LxxLL motifs to examine the impact that nuclear receptor LBD oligomerization state plays in coactivator binding (see Experimental Procedures). Table 2 details the results of these experiments, where SRC-1 binding to each LBD is examined when the LBD is alone and when the LBD is in the PXR/RXRa heterotetramer complex. In all cases, no PXR or RXRa ligands were added to these studies. SRC-1 LxxLL peptide motif binding to the RXRa LBD alone exhibits a $\mathrm{K}_{\mathrm{d}}$ of $1.56 \mu \mathrm{M}$ (Table 2). In contrast, SRC-1 peptide binding to the RXRa LBD in the PXR/RXRa heterotetramer complex exhibits a $\mathrm{K}_{\mathrm{d}}$ of $780 \mathrm{nM}$, which has a pvalue of 0.005 when compared to the RXRa LBD alone (Table 2). Similarly, SRC-1 peptide binding to the PXR LBD alone exhibits a $\mathrm{K}_{\mathrm{d}}$ of $1.18 \mu \mathrm{M}$ (Table 2). Again, in contrast, SRC-1 peptide binding to the PXR LBD in the PXR/RXRa heterotetramer complex exhibits a $\mathrm{K}_{\mathrm{d}}$ of $588 \mathrm{nM}$ (Figure 6B), which has a p-value of 0.009 when compared to the PXR LBD alone (Table 2). Indeed, when comparing the $\mathrm{K}_{\mathrm{d}}$ values of SRC-1 binding to the PXR LBD versus the RXRa LBD in the PXR/RXRa heterotetramer complex, they are statistically different with a p-value of 0.01 (Table 2). Thus, we conclude that the PXR LBD exhibits a higher affinity for the SRC-1 LxxLL motif employed relative to the RXRa LBD. In addition, these data indicate that both PXR and RXRa have significantly higher affinity for the coactivator SRC-1 when the LBDs are part of the PXR/RXRa heterotetramer complex, confirming the previous suggestion ${ }^{26}$ that the higher-order PXR/RXRa complex structure likely impacts the control of gene expression by PXR via improved coactivator binding.

\section{Recombinant Full-Length PXR/RXRa Complex Purification}

To our knowledge, the purification of intact PXR including the DNA-binding domain, linker region, and ligand-binding domain (DBD-linker-LBD, or "full-length") in quantities sufficient for structural or biochemical analysis has not been reported. We successfully purified the complex of full-length human PXR (residues 1-434) and human RXRa (residues 1-462). Each protein was expressed with a hexa-histidine tag in bacterial cells using codon-optimized constructs; human PXR also contained a maltose-binding protein fusion to increase solubility during the initial stages of purification. Both proteins required the presence of ligand (SR12813 and 9-cis-retinoic acid), and a linker with an LxxLL motif located on the $\mathrm{C}$-terminus of the $\mathrm{LBD}$, which as we have shown produces a stabilized AF-2 motif (Figure 6A). In the absence of this linked coactivator motif, PXR, in particular, was prone to aggregation. The proteins were purified separately through affinity chromatography and gel filtration, and then combined to form a complex prior to the proteolytic removal of PXR's MBD fusion protein. At that point, the PXR/RXRa complex was purified from a size-exclusion complex at an elution volume indicative of the $\sim 210 \mathrm{kDa}$ heterotetramer state. We obtained $\sim 40 \mathrm{mgs}$ of $>95 \%$ pure full-length PXR/RXRa complex from $18 \mathrm{~L}$ of 
bacterial expression media for PXR, and $6 \mathrm{~L}$ of RXRa. Thus, we were able to create the physiologically relevant state of human PXR and RXRa useful for in vitro studies such as DNA binding and structural characterization. Unfortunately, because the linked coactivator motifs appear critical for expression of soluble PXR, the current states of these receptors are not amenable to coregulator binding studies like those conducted for the LBD complex (Table 2).

\section{Full-Length PXR/RXRa DNA Binding}

The full-length PXR/RXRa complex was employed in fluorescence-based DNA binding assays for in vitro characterization of various pieces of duplex DNA to this important nuclear receptor assembly. The duplex DNAs examined are shown in Table 3, and include two fluorescently-labeled minimum response element sequences (DR3 FAM and ER6 FAM) and several unlabeled DNA competitors, with flanking sequences derived from the promoter region of CYP3A4. Dissociation constant values $\left(\mathrm{K}_{\mathrm{d}}\right)$ were first measured for the direct binding of the fluorescently DR3 FAM (Figure 7A) and ER6 FAM probes, and were found to be $206 \pm 53 \mathrm{nM}$ and $215 \pm 36 \mathrm{nM}$, respectively (Table 4). These initial results indicate that the receptors purified recombinantly in bacteria are functionally competent to bind DNA, and that they are able to associate with both the direct (DR) and everted (ER) repeat oligos derived from known PXR/RXR response elements.

Next, a set of competition binding experiments using DR3 and ER6 sequences with varying lengths of flanking bases were performed, and $\mathrm{K}_{\mathrm{i}}$ values were determined for each duplex oligonucleotide by examining their ability to compete away the corresponding labeled fluorescence probe (Table 4; Figure 7B). We found that the addition of flanking bases improves DNA binding for both the DR3 and ER6 sequences, with the strongest $\mathrm{K}_{\mathrm{i}}$ values observed for the $+9 /+9$ sequences, of 86.5 and $94.8 \mathrm{nM}$, respectively. A similar phenomenon has been described previously for the PPAR $\gamma / \mathrm{RXRa}$ nuclear receptor complex ${ }^{25} ; 31$. Removing flanking bases from either side of the response element half-sites has little effect on the DNA binding, as evidenced by competitors DR3 +9/+0 and DR3 +0/+9 (Table 4). This observation may be due to the strong binding by the receptor DBDs to the intact side of the DNA competitor, resulting in reduced anisotropy. However, the weakest DNA binding is observed when there are no flanking bases on either side (denoted by the +0 ); furthermore, binding is significantly hindered upon removing DNA bases from the response element sequence, and removal from both the $5^{\prime}$ and $3^{\prime}$ ends results in complete loss of binding (e.g., see competitors DR3 -2/-2 and ER6 -2/-2) (Table 4; Figure 7B). Importantly, we noted that DNA binding is strongest for the DR3 sequences relative to the ER6 sequences (Table 4). The addition of 6 to 9 DNA bases on either side of the HRE $(+9 /+9,+9 /+6$, $+6 /+9)$ yields similar binding affinities for both the DR3 and ER6 oligonucleotides, as evidenced by statistically non-significant P-values (Table 4 ). However, scaling back to only 3 additional bases $(+9 /+3,+3 /+9)$ on either side proves to be more detrimental to ER6 binding versus DR3, as suggested by the significant difference in $K_{i}$ values (Table 4 ). These observations suggest the extended spacer region between the half-sites negatively impacts DNA association for some oligonucleotides, such as those flanked by $+3 /+3$ and $+6 /+6$ duplex regions. Taken together, these data provide insights into the DNA binding characteristics of the full-length PXR/RXRa complex of human nuclear receptors.

\section{DISCUSSION}

PXR is the master regulator of the expression of drug and endobiotic metabolism genes in mammals and exhibits a distinctly promiscuous ability to bind to a wide variety of agonists. In this way, PXR is unique in function relative to other members of the nuclear receptor family of ligand-regulated transcription factors, of which it is a member. The PXR LBD also contains a $\sim 50$-residue insert unique to PXR relative to even closely related nuclear 
receptors, such as VDR, FXR and LXR. This insert encodes an additional helix and two $\beta$ strands with a tryptophan-zipper motif that creates a homodimer interface also unique to PXR. It was previously shown that the tryptophan and tyrosine residues that lock across this zipper are necessary for PXR LBD homodimerization and transcriptional activation, but do not impact the subcellular localization of PXR, or ligand and DNA association by the receptor ${ }^{27}$. The structure of PXR in complex with its obligate heterodimer partner RXRa had not been resolved until this study.

The crystal structures of the PXR/RXRa LBD complex presented here establish that the PXR homodimer, formed by a ten-stranded intermolecular $\beta$-sheet formed between the PXR LBD monomers, is maintained in the context of bound RXRa (Figures 1-3). This structure also reveals unique aspects to the higher-order PXR/RXRa LBD complex, particularly the presence of a curved pocket, $\sim 24 \AA$ wide and $\sim 15 \AA$ deep, formed between the two PXR LBD monomers (Figure 8). The amino acid composition on this surface is highlighted in Figure $8 \mathrm{~A}$, and we note that it is located $\sim 35 \AA$ from the coactivator LxxLL motifs bound to the AF-2 sites of each PXR monomer. Charged residues, including D230, K210, D310, E309, K226, E300, R216, R303, E218, and D219, and polar residues, including S231, T311, S212, T296, T298, Y225, Y306, S305, Q214, N224, and S221, create this curved surface.

Furthermore, electrostatic considerations demonstrate that this surface exhibits two negatively charged "ridge" regions on either side of one positively charged "valley" (Figure 8B). Residues that create this electrostatic feature (namely residues 211-230 and 298-310 that comprises the PXR $\beta$-sheet dimerization interface) are highly conserved in PXRs across species (NCBI BLASTp, inputting human PXR LBD residues 130-434) ${ }^{26 ; 32}$. A concave, charged and conserved face suggests this region plays important role in PXR function, possibly by forming specific macromolecular interactions. For example, this intermolecular electrostatic surface may serve as a binding site for one of the PXR DNA-binding domains (DBDs). Alternatively, or in addition, this region may act as an interface for other proteins, such as the transcriptional coactivator SRC-1. Full-length SRC-1 contains multiple LxxLL motifs that are known to bind to various nuclear receptor AF-2 regions $33 ; 34$. As such, it is interesting to speculate that the PXR homodimer binds to multiple LxxLL motifs of a single coactivator protein, and the intervening residues between these binding motifs may be passed through the cupped- $\beta$-sheet region to stabilize a higher-order PXR/SRC-1 complex. Further work will be required to test such a hypothesis, which is expected to be unique to PXR given that it is the only member of the NR superfamily that contains these inserted structural motifs.

We also demonstrate that PXR and RXRa each associate with transcriptional coactivator LxxLL motifs with higher affinity when they are part of the PXR/RXRa complex than when each receptor is in isolation (Table 2). The increase in binding affinity for coactivators in nuclear receptor complexes versus individual receptors has previously been noted for RXR, RAR, and CAR ${ }^{35 ; 36}$. The increased binding affinity $\left(K_{d}\right)$ was shown to be very significant by a P-value calculation for both PXR and RXRa versus the PXR/RXRa complex. Coactivator binding affinity is increased 2-fold for both nuclear receptors upon complex formation. Although there are no significant structural changes between the structures of individual nuclear receptors versus the complexed forms, it is clear that both nuclear receptors act in a cooperative fashion to greatly improve the mechanism of coregulator recruitment and binding. Furthermore, the presence of agonist ligands for PXR (SR12813) and RXRa (9-cis-retinoic acid) in excess acts to simultaneously stabilize complex formation and to increase SRC-1 binding, which has previously been noted ${ }^{35 ; 36}$. Molecular dynamics investigations of PXR both alone and with RXRa, as well as other receptors in their physiologically-relevant complexes, have indicated that the AF-2 regions of nuclear receptors move in a correlated fashion when the LBDs are complexed to their appropriate 
partner, either as a homodimer or heterodimer with $\mathrm{RXRa}{ }^{16}$. The experimental results presented here are consistent with these computational results, and further support the conclusion that protein motion is a critical factor in function.

\section{EXPERIMENTAL PROCEDURES}

\section{Cloning and Expression of the PXR/RXRa LBD Complex}

The PXR LBD (residues 130-434) was PCR amplified from the full-length, codonoptimized PXR gene (synthesized by GenScript) fused to a 5-residue glycine-serine linker (GGSGG) and the human SRC-1 coactivator fragment (residues 678-700,

SSHSSLTERHKILHRLLQEGSPS). This construct was previously used in successful crystallization studies for the PXR LBD ${ }^{25}$. The PXR LBD construct was cloned into the HIS-LIC pMCSG vector (acquired from the Sondek Lab at UNC) for protein expression. RXRa LBD (residues 227-462) was PCR amplified from the full-length, codon-optimized RXRa gene fused to the same glycine-serine linker with the SRC-1 coactivator fragment (GenScript). The coding region for the RXRa LBD was placed into pET-30b (Invitrogen) expression vector without a His-tag fused to the protein. Terrific broth media was inoculated with a saturated culture of BL21 AI cells transformed with the HIS-LIC plasmid containing the PXR LBD construct and allowed to shake at $37^{\circ} \mathrm{C}$. When the cells reach an OD600 of $\sim 1.0$ the temperature was reduced to $16^{\circ} \mathrm{C}$, at which time $\mathrm{L}$-arabinose was added to each flask up to a final concentration of $0.1 \%$ and IPTG was added (final concentration of 0.2 $\mathrm{mM}$ ) to induce protein expression. After shaking overnight, cells were collected by centrifugation at $4,500 \times \mathrm{g}$ for 20 minutes and stored at $-80^{\circ} \mathrm{C}$. The growth and expression of RXRa LBD was carried out in a similar manner as the PXR LBD described above. When the RXRa LBD growth achieved an OD600 of $\sim 1.0$, the temperature was reduced to $16^{\circ} \mathrm{C}$. A final concentration of $0.1 \% \mathrm{~L}$-arabinose was added when temperature reached $\sim 16^{\circ} \mathrm{C}$, and expression was induced at $16{ }^{\circ} \mathrm{C}$ with a final concentration of $0.2 \mathrm{mM}$ IPTG.

\section{LBD Complex Formation and Purification}

PXR LBD and RXRa LBD proteins were co-purified to encourage complex formation. In an approximate 3:1 PXR to RXRa cell ratio, to account for the higher expression of RXRa relative to PXR, cell pellets were separately resuspended in Buffer A (50 mM HEPES pH $7.5,30 \mathrm{mM}$ imidazole, $250 \mathrm{mM} \mathrm{NaCl}, 5 \%$ glycerol) supplemented with a protease inhibitor tablet (Roche), DNase, and lysozyme. After sonication, the cell lysate was clarified by highspeed centrifugation at $14,500 \times \mathrm{g}$ for $50 \mathrm{~min}$. The supernatant was removed and syringe filtered through a 0.22 um filter. PXR and RXRa LBD clarified cell lysates were then combined prior to further purification. Excess amount of PXR ligand was added to the lysate to help stabilize the protein throughout the purification process. Clarified lysate was loaded onto the Äktaxpress FPLC system (Amersham Biosciences) for a gradient-elution using Buffer B (50 mM HEPES pH 7.5, $300 \mathrm{mM}$ imidazole, $250 \mathrm{mM} \mathrm{NaCl}, 5 \%$ glycerol) on $\mathrm{Ni}$ His-Trap (GE Healthcare) columns. Excess RXRa LBD protein was washed away at low concentrations of Buffer B during the gradient elution as this protein was untagged. Purest fractions containing PXR-RXRa complex (determined by SDS-PAGE) were combined and concentrated as much as possible without destabilizing the protein. While concentrating the PXR/RXRa LBD complex, additional ligand was added periodically to compensate for any ligand washed away during Ni-column purification. LBD complex was dialyzed overnight into a TEV cleavage/Gel filtration buffer ( $25 \mathrm{mM}$ HEPES pH 7.5, $150 \mathrm{mM} \mathrm{NaCl}, 1 \mathrm{mM}$ DTT, and 5\% glycerol) in the presence of TEV protease to cleave the His-fusion tag from the PXR LBD. Samples were concentrated and loaded on the FPLC system for size exclusion purification using a HiLoad ${ }^{\mathrm{TM}} 16 / 60$ Superdex $^{\mathrm{TM}} 200$ gel filtration column. The LBD complex was eluted in $25 \mathrm{mM}$ HEPES pH 7.5, $150 \mathrm{mM} \mathrm{NaCl}, 1 \mathrm{mM}$ DTT, and 5\% 
glycerol. Purity of each fraction was assessed by SDS-PAGE and $>95 \%$ pure fractions were combined.

\section{LBD Complex Crystallization, Data Collection, and Structure Solution}

Purified PXR/RXRa LBD complex was shipped to the Hauptman-Woodward Medical Research Institute in Buffalo, NY to screen several crystallization conditions using their automated crystallization setup ${ }^{37}$. An initial crystal hit was identified in $20 \%(\mathrm{w} / \mathrm{v})$ PEG 8000, $0.1 \mathrm{M}$ magnesium chloride, and $0.1 \mathrm{M}$ bis-tris propane $\mathrm{pH} 7.0$ at $4{ }^{\circ} \mathrm{C}$. Crystallization optimization was carried out in-house, by grid optimization screens around the original hit condition. Varying precipitant concentration, salt concentration, and protein to crystallant drop ratio was successful in reproducing these crystals. Additional crystallization optimization experiments were performed to improve crystal growth, as initial crystals grew as $2 \mathrm{D}$ plates, with only a few crystals growing successfully in the $3^{\text {rd }}$ dimension. Decoupling experiments ${ }^{38}$ as well as alternating the salt anion $(\mathrm{MgX}$, where $\mathrm{X}=$ acetate, formate, sulfate) were employed. Optimized crystals were harvested and streaked through mother liquor supplemented with $20 \%$ (v/v) glycerol to cryo-protect the crystals for X-ray data collection.

Crystals were shipped to GM/CA-CAT (Beamline 23) at APS for X-ray data collection. Data were collected in $0.2^{\circ}$ oscillations for each crystal. Diffraction data were obtained on crystals of apo-PXR/RXRa LBD complex and SR12813-bound PXR/RXRa LBD complex. Data collection statistics are presented in Table 1. Data from both forms were indexed in the space group $\mathrm{P} 2{ }_{1} 2{ }_{1}{ }_{2}$. Cell constants for the apo-form were $\mathrm{a}=70.26, \mathrm{~b}=109.6, \mathrm{c}=169.9$; the SR12813-bound complex cell constants were $a=70.09, b=120.3, c=175.8$. XDS ${ }^{39}$ was used to process the apo-data and HKL2000 ${ }^{40}$ was utilized for data reduction of the SR12813bound data. The SR12813-bound LBD complex was solved by molecular replacement using Phaser ${ }^{41}$ and ensemble search methods using monomers derived from PDB ID 1NRL (PXR LBD) ${ }^{11}$ and PDB ID 3PCU (RXRa LBD) ${ }^{42}$. The first round of molecular replacement successfully placed two PXR monomers, which form the PXR homodimer seen the PXR LBD crystal structures 11; 12; 16; 17; 18; 27. Two consecutive rounds of molecular replacement were employed; the first located the two PXR LBD monomers forming the central PXR homodimer; the second placed an RXRa LBD monomer adjacent to each PXR LBD monomer. Utilizing the SR12813-bound LBD complex as a search model, the apo-complex was solved by molecular replacement using Phaser ${ }^{41}$.

Structures were manually built using Coot and $2 \mathrm{Fo}-\mathrm{Fc}$ and Fo-Fc electron density maps ${ }^{43}$. The structures were refined using simulated annealing, torsion angle, and B-factor refinement using Phenix ${ }^{44}$. Furthermore, the data proved to be anisotropic and standard anisotropic refinement methods were utilized in Phenix $^{44}$, which improved map quality for subsequent manual refinement. Phenix creates a modified, anisotropy-corrected, data file during each refinement run; thus, models were always refined against anisotropy-corrected data. Model quality during refinement was monitored using both the crystallographic $\mathrm{R}$ and cross-validating R-free statistics ${ }^{45}$. Refinement statistics for both models are presented in Table 1.

\section{SRC-1 Peptide Binding Assays with the LBD Complex}

To compare the binding properties of the SRC-1 coactivator peptide to PXR, RXRa, and the PXR/RXRa complex, new LBD constructs were generated that allowed for the expression of wild-type LBDs without the fused coactivator peptide. PCR was used to insert a stop codon before the start of the 5-residue glycine/serine linker at the C-terminal end of both nuclear receptors. The PXR LBD is known to be unstable and express poorly in the absence of the coactivator peptide; as such, the wild-type PXR LBD was cloned into the MBP-LIC 
pMCSG vector (acquired from the Sondek Lab at UNC) to utilize a MBP-fusion tag to increase stability and expression. The following protein samples were purified in a similar manner as the SRC-1 fused LBDs: wild-type PXR and RXRa, and the complexes PXRSRC-1/RXRa no SRC-1 and PXR no SRC1/RXRa-SRC-1. The combination of SRC-1 fused PXR with wild type unfused RXRa and vice versa allows for the assessment of SRC-1 binding to each of the individual nuclear receptors in a complexed state. A fluorescein labeled SRC-1 peptide (5-FAM-CPSSHSSLTERHKILHRLLQEGSPS), residues 676-700, was acquired from GenScript to utilize in fluorescence anisotropy binding experiments. SRC-1 coactivator binding reactions were composed of $50 \mathrm{nM}$ FAM-SRC-1 peptide, assay buffer (25 mM HEPES pH 7.5, $100 \mathrm{mM} \mathrm{NaCl}, 5 \%$ glycerol, and $1 \mathrm{mM} \mathrm{DTT}$ ), and various concentrations of protein. The SRC-1 peptide and protein buffer solutions were pre-diluted to yield a final assay concentration of $100 \mathrm{mM} \mathrm{NaCl}$. Fluorescence anisotropy was measured (excitation $=485 \mathrm{~nm}$, emission $=520 \mathrm{~nm}$ ) using a PHERAstar Plus microplate reader (BMG Labtech). Data acquired was analyzed using Microsoft Excel and Sigmaplot 11.0. Dissociation constants $\left(\mathrm{K}_{\mathrm{d}}\right)$ were calculated by fitting to a nonlinear regression, onesite saturation binding model and the statistical significance of $K_{d}$ values was assessed by calculating P-values in Sigmaplot 11.0.

\section{Cloning and Expression of the Full-length PXR/RXR $\alpha$ Complex}

Prior knowledge of PXR-LBD expression suggests that the full-length receptor would be far more difficult to express in a soluble, well-folded form and in sufficient quantities for further experimentation. The coexpression of SRC-1 peptide fragment with PXR LBD has previously been shown to facilitate PXR-LBD expression ${ }^{11 ; 25}$, and so co-expression of the SRC-1 fragment was crucial for protein expression. However, instead of co-expression of the SRC-1 peptide as was previously done ${ }^{11 ;} 16 ; 17 ; 18 ; 27{ }^{46}$, tethered versions of full-length PXR and RXR were constructed by fusing a glycine-serine linker at the end of the protein followed by the SRC-1 fragment. Literature has demonstrated that this technique is successful at producing soluble, stable protein, permanently linked to the SRC-1 coactivator ${ }^{25}$. To increase full-length protein expression, codon optimization using the services of GenScript was utilized to construct each gene, with the addition of the tethered SRC-1 fragment.

Both genes were cloned in the MBP-LIC pMCSG vector (acquired from the Sondek Lab at $\mathrm{UNC}$ ), as the MBP-fusion would additionally help the stability and solubility of the proteins as they are being expressed. E. coli BL21 (DE3) AI cells were transformed with either the PXR or RXRa full-length plasmid for separate protein expression. Terrific broth media was inoculated with a saturated culture of BL21 AI cells transformed with the MBP-PXR plasmid and allowed to shake at $37^{\circ} \mathrm{C}$. When the cells reach and OD600 of $\sim 1.4-1.6$ the temperature was turned down to $15^{\circ} \mathrm{C}$. At $\sim 17^{\circ} \mathrm{C}$ L-arabinose was added to each flask up to a final concentration of $0.1 \%$. When the temperature achieved $15^{\circ} \mathrm{C}$, IPTG was added (final concentration of $1 \mathrm{mM}$ ) to induce protein expression. After shaking overnight, cells were collected by centrifugation at $4,500 \times \mathrm{g}$ for $20 \mathrm{~min}$ and stored at $-80^{\circ} \mathrm{C}$. These growths yielded on average 2-3 mg/L of full-length PXR protein. The growth and expression of RXRa was carried out in a similar manner as PXR described above. When the RXRa growth achieved an OD600 of $\sim 1.4-1.6$, the temperature was reduced to $17^{\circ} \mathrm{C}$. A final concentration of $0.1 \% \mathrm{~L}$-arabinose was added when temperature reached $\sim 19^{\circ} \mathrm{C}$, and expression was induced at $17^{\circ} \mathrm{C}$ with a final concentration of $1 \mathrm{mM}$ IPTG. With this protocol, $\sim 10 \mathrm{mg} / \mathrm{L}$ of full-length $\mathrm{RXRa}$ is produced on average.

\section{Purification and Formation of the Full-length Complex}

PXR and RXRa were each purified similarly but individually prior to complex formation. Cell pellets were resuspended in Buffer A (50 mM HEPES pH 7.5, $50 \mathrm{mM}$ imidazole, 500 
$\mathrm{mM} \mathrm{NaCl}, 10 \%$ glycerol) supplemented with a protease inhibitor tablet (Roche), DNase, and lysozyme. After sonication, the cell lysate was clarified by high-speed centrifugation at $14,500 \times \mathrm{g}$ for 50 mins. The supernatant was removed and syringe filtered through a $0.22 \mathrm{um}$ filter. For PXR purifications, an excess amount of ligand was added to the lysate to help stabilize the protein throughout the purification process. Clarified lysate was loaded onto the Äktaxpress FPLC system (Amersham Biosciences) for a step-purification, up to $500 \mathrm{mM}$ imidazole, on Ni His-Trap (GE Healthcare) columns. Purest fractions (determined by SDSPAGE) were combined and concentrated as much as possible without destabilizing the protein. While concentrating PXR, additional ligand was added periodically to compensate for any ligand washed away during Ni-column purification. Concentrated samples were loaded on the FPLC system for sizing purification using a HiLoad ${ }^{\mathrm{TM}} 16 / 60$ Superdex $^{\mathrm{TM}} 200$ gel filtration column. Each protein was eluted into $20 \mathrm{mM}$ Tris- $\mathrm{HCl} \mathrm{pH} \mathrm{7.5,250} \mathrm{mM} \mathrm{NaCl}$, $1 \mathrm{mM}$ TCEP, and 5\% glycerol. Purity of each fraction was assessed by SDS-PAGE and fractions of $>95 \%$ purity were combined. After each protein was individually purified, $5 \mathrm{~mL}$ reactions were prepared to form the PXR/RXRa complex for a final round of gel filtration. One reaction consisted of $30 \mu \mathrm{M}$ each of PXR and RXRa, 5-times excess of PXR ligand, 2times excess of the RXRa ligand 9-cis-retinoic acid. TEV protease was also added to the reaction to cleave the MBP-fusion tag from each protein. The complex formation reactions were directly injected onto the S200 gel filtration column after a $>8 \mathrm{~h}$ incubation at $4{ }^{\circ} \mathrm{C}$ to allow complete cleavage to occur. Two peaks eluted from the sizing column, the first being the PXR/RXRa complex and the second the now cleaved MBP-fusion tag. This reaction protocol for complex formation yielded the purified hetero-complex, as assessed by SDSPAGE showing two protein bands representing full-length PXR and RXRa.

\section{DNA Binding Studies with the Full-length Complex}

The purified full-length PXR/RXRa was utilized for in vitro experiments to determine DNA binding properties of the complex. Several different types of duplex DNA containing response elements (REs) were procured to test the binding affinity for each type of RE as well as to assess the necessity of flanking bases for improved DNA binding. The sequences of each duplex DNA tested are listed in Table 3.

Two DNA binding assays were utilized to measure binding of the nuclear receptor complex to REs. The first assay used fluorescein-labeled duplex DNA (Table 3) to measure the dissociation constant, $\mathrm{K}_{\mathrm{d}}$, for a DR3 and ER6 type DNA from the CYP3A4 promoter region. These pieces of DNA contained the minimum number of bases to create the repeat. This DNA binding assay consisted of several different concentrations of the complex, starting at a maximum of $5 \mu \mathrm{M}$. Twenty-five microliters of the total assay volume consisted of the nuclear receptor complex and the assay buffer, which was configured to create a final $\mathrm{NaCl}$ concentration of $100 \mathrm{mM}$. Another $25 \mu \mathrm{L}$ of the DNA probe solution was added (final concentration of $50 \mathrm{nM}$ ), making the final reaction volume $50 \mu \mathrm{L}$. Fluorescence anisotropy was detected using a PHERAstar Plus microplate reader (BMG Labtech). Data acquired was analyzed using Microsoft Excel and Sigmaplot 11.0. $\mathrm{K}_{\mathrm{d}}$ values were calculated for the DR3 FAM and ER6 FAM and subsequently used to calculate $\mathrm{K}_{\mathrm{i}}$ values for each DNA competitor.

The second DNA binding assay is competition-based to measure the binding of several pieces of duplex DNA with different lengths of flanking bases (Table 3) in addition to the minimum RE repeats. This assay was composed of a constant protein concentration (200 $\mathrm{nM})$ and a constant concentration of fluorescein-labeled duplex DNA $(50 \mathrm{nM})$. A range of unlabeled DNA competitor concentrations were used in each assay, with a maximum concentration of $10 \mu \mathrm{M}$. Addition of each component yielded a total reaction volume of 50 $\mu \mathrm{L}$ and a final $\mathrm{NaCl}$ concentration of $100 \mathrm{mM}$. Data was collected and analyzed as with the first DNA binding assay described above. The inhibition constant values $\left(\mathrm{K}_{\mathrm{i}}\right)$ were calculated using the Cheng-Prusoff equation ${ }^{47}$. These values are presented in Table 4. 


\section{Acknowledgments}

Supported by NIH grant CA98468 (MRR).

\section{References}

1. Handschin C, Meyer UA. Induction of drug metabolism: the role of nuclear receptors. Pharmacol Rev. 2003; 55:649-73. [PubMed: 14657421]

2. Miller RT, Willson TM. Regulation of xenobiotic metabolism by orphan nuclear receptors. Toxicol Pathol. 2001; 29:3-5. [PubMed: 11215681]

3. Moore DD. Regulation of drug transport by new xenobiotic receptors. Pharmacogenomics J. 2001; 1:224-5. [PubMed: 11908760]

4. Omiecinski CJ, Vanden Heuvel JP, Perdew GH, Peters JM. Xenobiotic metabolism, disposition, and regulation by receptors: from biochemical phenomenon to predictors of major toxicities. Toxicol Sci. 120(Suppl 1):S49-75. [PubMed: 21059794]

5. Sonoda J, Evans R. Biological function and mode of action of nuclear xenobiotic receptors. Pure and Applied Chemistry. 2003; 75:1733-1742.

6. Kliewer SA, Goodwin B, Willson TM. The nuclear pregnane X receptor: a key regulator of xenobiotic metabolism. Endocr Rev. 2002; 23:687-702. [PubMed: 12372848]

7. Blumberg B, Sabbagh W Jr, Juguilon H, Bolado J Jr, van Meter CM, Ong ES, Evans RM. SXR, a novel steroid and xenobiotic-sensing nuclear receptor. Genes Dev. 1998; 12:3195-205. [PubMed: 9784494]

8. Bertilsson G, Heidrich J, Svensson K, Asman M, Jendeberg L, Sydow-Backman M, Ohlsson R, Postlind H, Blomquist P, Berkenstam A. Identification of a human nuclear receptor defines a new signaling pathway for CYP3A induction. Proc Natl Acad Sci U S A. 1998; 95:12208-13. [PubMed: 9770465]

9. Kliewer SA, Moore JT, Wade L, Staudinger JL, Watson MA, Jones SA, McKee DD, Oliver BB, Willson TM, Zetterstrom RH, Perlmann T, Lehmann JM. An orphan nuclear receptor activated by pregnanes defines a novel steroid signaling pathway. Cell. 1998; 92:73-82. [PubMed: 9489701]

10. Wallace BD, Redinbo MR. Xenobiotic-sensing nuclear receptors involved in drug metabolism: a structural perspective. Drug Metab Rev. 45:79-100. [PubMed: 23210723]

11. Watkins RE, Davis-Searles PR, Lambert MH, Redinbo MR. Coactivator binding promotes the specific interaction between ligand and the pregnane X receptor. J Mol Biol. 2003; 331:815-28. [PubMed: 12909012]

12. Watkins RE, Maglich JM, Moore LB, Wisely GB, Noble SM, Davis-Searles PR, Lambert MH, Kliewer SA, Redinbo MR. 2.1 A crystal structure of human PXR in complex with the St. John's wort compound hyperforin. Biochemistry. 2003; 42:1430-8. [PubMed: 12578355]

13. Watkins RE, Wisely GB, Moore LB, Collins JL, Lambert MH, Williams SP, Willson TM, Kliewer SA, Redinbo MR. The human nuclear xenobiotic receptor PXR: structural determinants of directed promiscuity. Science. 2001; 292:2329-33. [PubMed: 11408620]

14. Onate SA, Tsai SY, Tsai MJ, O'Malley BW. Sequence and characterization of a coactivator for the steroid hormone receptor superfamily. Science. 1995; 270:1354-7. [PubMed: 7481822]

15. Allenby G, Bocquel MT, Saunders M, Kazmer S, Speck J, Rosenberger M, Lovey A, Kastner P, Grippo JF, Chambon P, et al. Retinoic acid receptors and retinoid X receptors: interactions with endogenous retinoic acids. Proc Natl Acad Sci U S A. 1993; 90:30-4. [PubMed: 8380496]

16. Teotico DG, Bischof JJ, Peng L, Kliewer SA, Redinbo MR. Structural basis of human pregnane X receptor activation by the hops constituent colupulone. Mol Pharmacol. 2008; 74:1512-20. [PubMed: 18768384]

17. Xue Y, Moore LB, Orans J, Peng L, Bencharit S, Kliewer SA, Redinbo MR. Crystal structure of the pregnane $\mathrm{X}$ receptor-estradiol complex provides insights into endobiotic recognition. Mol Endocrinol. 2007; 21:1028-38. [PubMed: 17327420]

18. Cheng Y, Redinbo MR. Activation of the human nuclear xenobiotic receptor PXR by the reverse transcriptase-targeted anti-HIV drug PNU-142721. Protein Sci. 20:1713-9. [PubMed: 21805522] 
19. Chrencik JE, Orans J, Moore LB, Xue Y, Peng L, Collins JL, Wisely GB, Lambert MH, Kliewer SA, Redinbo MR. Structural disorder in the complex of human pregnane X receptor and the macrolide antibiotic rifampicin. Mol Endocrinol. 2005; 19:1125-34. [PubMed: 15705662]

20. Bourguet W, Vivat V, Wurtz JM, Chambon P, Gronemeyer H, Moras D. Crystal structure of a heterodimeric complex of RAR and RXR ligand-binding domains. Mol Cell. 2000; 5:289-98. [PubMed: 10882070]

21. Gampe RT Jr, Montana VG, Lambert MH, Miller AB, Bledsoe RK, Milburn MV, Kliewer SA, Willson TM, Xu HE. Asymmetry in the PPARgamma/RXRalpha crystal structure reveals the molecular basis of heterodimerization among nuclear receptors. Mol Cell. 2000; 5:545-55. [PubMed: 10882139]

22. Suino K, Peng L, Reynolds R, Li Y, Cha JY, Repa JJ, Kliewer SA, Xu HE. The nuclear xenobiotic receptor CAR: structural determinants of constitutive activation and heterodimerization. Mol Cell. 2004; 16:893-905. [PubMed: 15610733]

23. Svensson S, Ostberg T, Jacobsson M, Norstrom C, Stefansson K, Hallen D, Johansson IC, Zachrisson K, Ogg D, Jendeberg L. Crystal structure of the heterodimeric complex of LXRalpha and RXRbeta ligand-binding domains in a fully agonistic conformation. Embo J. 2003; 22:462533. [PubMed: 12970175]

24. Xu RX, Lambert MH, Wisely BB, Warren EN, Weinert EE, Waitt GM, Williams JD, Collins JL, Moore LB, Willson TM, Moore JT. A structural basis for constitutive activity in the human CAR/ RXRalpha heterodimer. Mol Cell. 2004; 16:919-28. [PubMed: 15610735]

25. Chandra V, Huang P, Hamuro Y, Raghuram S, Wang Y, Burris TP, Rastinejad F. Structure of the intact PPAR-gamma-RXR-alpha nuclear receptor complex on DNA. Nature. 2008:350-356. [PubMed: 19043829]

26. Ray A, Siegel MD, Prefontaine KE, Ray P. Anti-inflammation: direct physical association and functional antagonism between transcription factor NF-KB and the glucocorticoid receptor. Chest. 1995; 107:139S. [PubMed: 7874997]

27. Noble SM, Carnahan VE, Moore LB, Luntz T, Wang H, Ittoop OR, Stimmel JB, Davis-Searles PR, Watkins RE, Wisely GB, LeCluyse E, Tripathy A, McDonnell DP, Redinbo MR. Human PXR forms a tryptophan zipper-mediated homodimer. Biochemistry. 2006; 45:8579-89. [PubMed: 16834332]

28. Onate SA, Boonyaratanakornkit V, Spencer TE, Tsai SY, Tsai MJ, Edwards DP, O'Malley BW. The steroid receptor coactivator- 1 contains multiple receptor interacting and activation domains that cooperatively enhance the activation function 1 (AF1) and AF2 domains of steroid receptors. J Biol Chem. 1998; 273:12101-8. [PubMed: 9575154]

29. Orans J, Teotico DG, Redinbo MR. The nuclear xenobiotic receptor pregnane X receptor: recent insights and new challenges. Mol Endocrinol. 2005; 19:2891-900. [PubMed: 15961506]

30. Delvecchio CJ, Bilan P, Nair P, Capone JP. LXR-induced reverse cholesterol transport in human airway smooth muscle is mediated exclusively by ABCA1. Am J Physiol Lung Cell Mol Physiol. 2008; 295:L949-57. [PubMed: 18820007]

31. Castelein H, Declercq PE, Baes M. DNA binding preferences of PPAR alpha/RXR alpha heterodimers. Biochem Biophys Res Commun. 1997; 233:91-5. [PubMed: 9144402]

32. Altschul SF, Gish W, Miller W, Myers EW, Lipman DJ. Basic local alignment search tool. J Mol Biol. 1990; 215:403-10. [PubMed: 2231712]

33. Darimont BD, Wagner RL, Apriletti JW, Stallcup MR, Kushner PJ, Baxter JD, Fletterick RJ, Yamamoto KR. Structure and specificity of nuclear receptor-coactivator interactions. Genes Dev. 1998; 12:3343-56. [PubMed: 9808622]

34. Gee AC, Carlson KE, Martini PG, Katzenellenbogen BS, Katzenellenbogen JA. Coactivator peptides have a differential stabilizing effect on the binding of estrogens and antiestrogens with the estrogen receptor. Mol Endocrinol. 1999; 13:1912-23. [PubMed: 10551784]

35. Pogenberg V, Guichou JF, Vivat-Hannah V, Kammerer S, Perez E, Germain P, de Lera AR, Gronemeyer H, Royer CA, Bourguet W. Characterization of the interaction between retinoic acid receptor/retinoid $\mathrm{X}$ receptor (RAR/RXR) heterodimers and transcriptional coactivators through structural and fluorescence anisotropy studies. J Biol Chem. 2005; 280:1625-33. [PubMed: $15528208]$ 
36. Wright E, Vincent J, Fernandez EJ. Thermodynamic characterization of the interaction between CAR-RXR and SRC-1 peptide by isothermal titration calorimetry. Biochemistry. 2007; 46:86270. [PubMed: 17223708]

37. Luft JR, Collins RJ, Fehrman NA, Lauricella AM, Veatch CK, DeTitta GT. A deliberate approach to screening for initial crystallization conditions of biological macromolecules. J Struct Biol. 2003; 142:170-9. [PubMed: 12718929]

38. Saridakis E, Chayen NE. Improving protein crystal quality by decoupling nucleation and growth in vapor diffusion. Protein Sci. 2000; 9:755-7. [PubMed: 10794418]

39. Kabsch W. Xds Acta Crystallogr D Biol Crystallogr. 66:125-32.

40. Otwinowski, Z.; Minor, W.; Charles, W.; Carter. Methods in Enzymology. Vol. 276. Academic Press; 1997. [20] Processing of X-ray diffraction data collected in oscillation mode; p. 307-326.

41. McCoy AJ, Grosse-Kunstleve RW, Adams PD, Winn MD, Storoni LC, Read RJ. Phaser crystallographic software. J Appl Crystallogr. 2007; 40:658-674. [PubMed: 19461840]

42. Wei P, Zhang J, Egan-Hafley M, Liang S, Moore DD. The nuclear receptor CAR mediates specific xenobiotic induction of drug metabolism. Nature. 2000; 407:920-3. [PubMed: 11057673]

43. Emsley P, Cowtan K. Coot: model-building tools for molecular graphics. Acta Crystallogr D Biol Crystallogr. 2004; 60:2126-32. [PubMed: 15572765]

44. Adams PD, Grosse-Kunstleve RW, Hung LW, Ioerger TR, McCoy AJ, Moriarty NW, Read RJ, Sacchettini JC, Sauter NK, Terwilliger TC. PHENIX: building new software for automated crystallographic structure determination. Acta Crystallogr D Biol Crystallogr. 2002; 58:1948-54. [PubMed: 12393927]

45. Brunger AT. Free R value: cross-validation in crystallography. Methods Enzymol. 1997; 277:36696. [PubMed: 18488318]

46. Carnahan VE, Redinbo MR. Structure and function of the human nuclear xenobiotic receptor PXR. Curr Drug Metab. 2005; 6:357-67. [PubMed: 16101574]

47. Cheng Y, Prusoff WH. Relationship between the inhibition constant (K1) and the concentration of inhibitor which causes 50 per cent inhibition (I50) of an enzymatic reaction. Biochem Pharmacol. 1973; 22:3099-108. [PubMed: 4202581] 
- Structure of the heterotetramer formed between human PXR and RXRa

- Heterotetramer unprecedented in nuclear receptor family of transcription factors

- Receptors in heterotetramer exhibit enhanced association with coregulators

- Purified full-length PXR and RXRa from recombinant bacterial system

- DNA binding studies of full-length receptors with DR and ER response elements 


\section{A $S R C-1$}

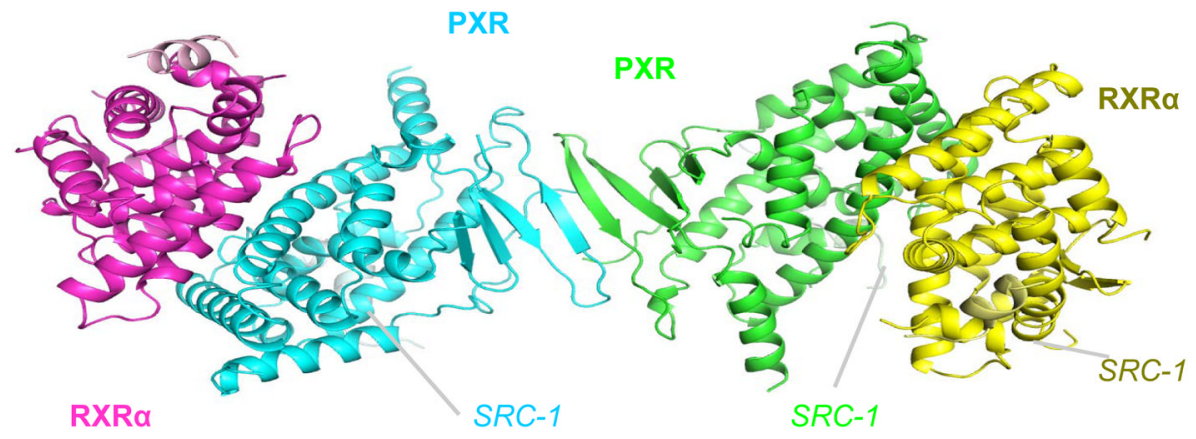

B

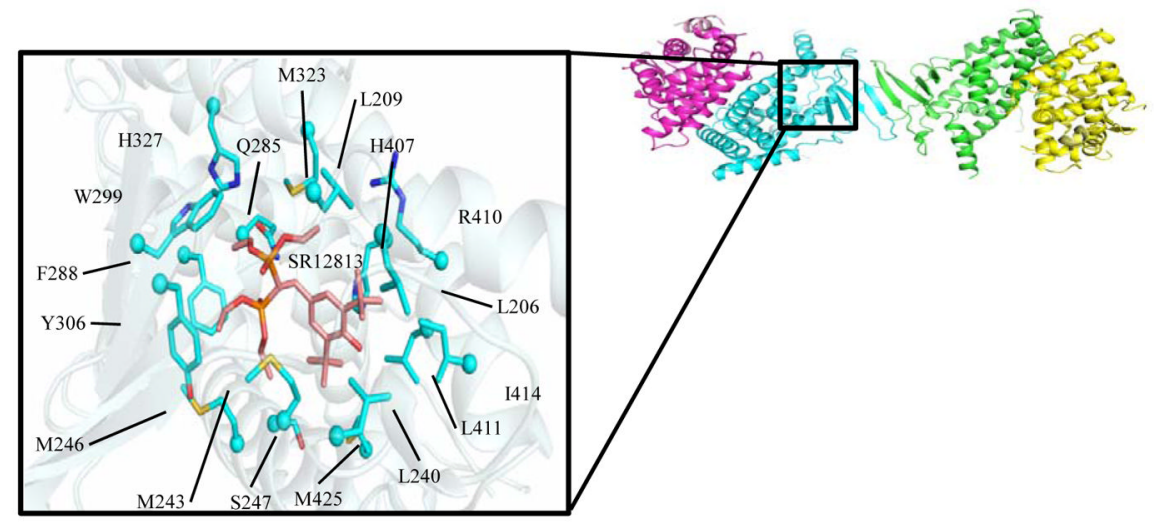

Figure 1. Structure of the PXR-RXR LBD Complex

A. $2.8 \AA$ resolution structure of the complex formed between the ligand binding domains (LBDs) of human PXR (cyan, green) and RXRa (magenta, yellow), with the SRC-1 peptides bound to each LBD indicated. B. In the ligand bound complex of PXR and RXRa, the cholesterol-lowering compound SR12813 is contacted by the amino acid side chains indicated. 

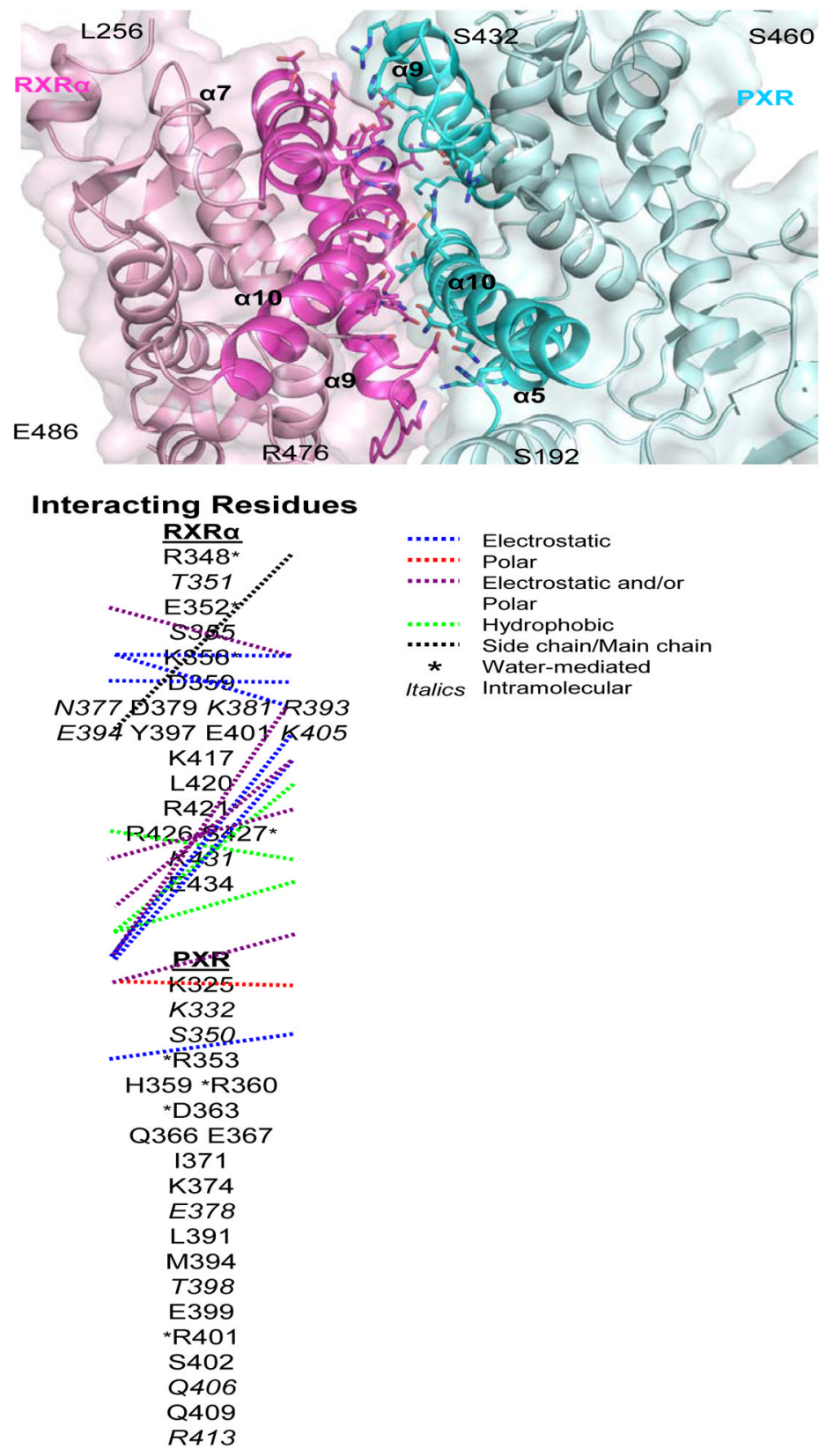

Figure 2. PXR-RXR LBD Complex Interface

Regions of a5, a 9 and a 10 of human PXR (cyan) contact regions of a 7, a 9 and a 10 of human RXRa (magenta) using the residues listed below. The specific residue-residue interactions are detailed with connecting lines (blue= electrostatic, red= polar, purple=electrostatic and/or polar, green= hydrophobic, black= side chain-main chain), an asterisk (*= water-mediated), and italics (italics $=$ intramolecular). 

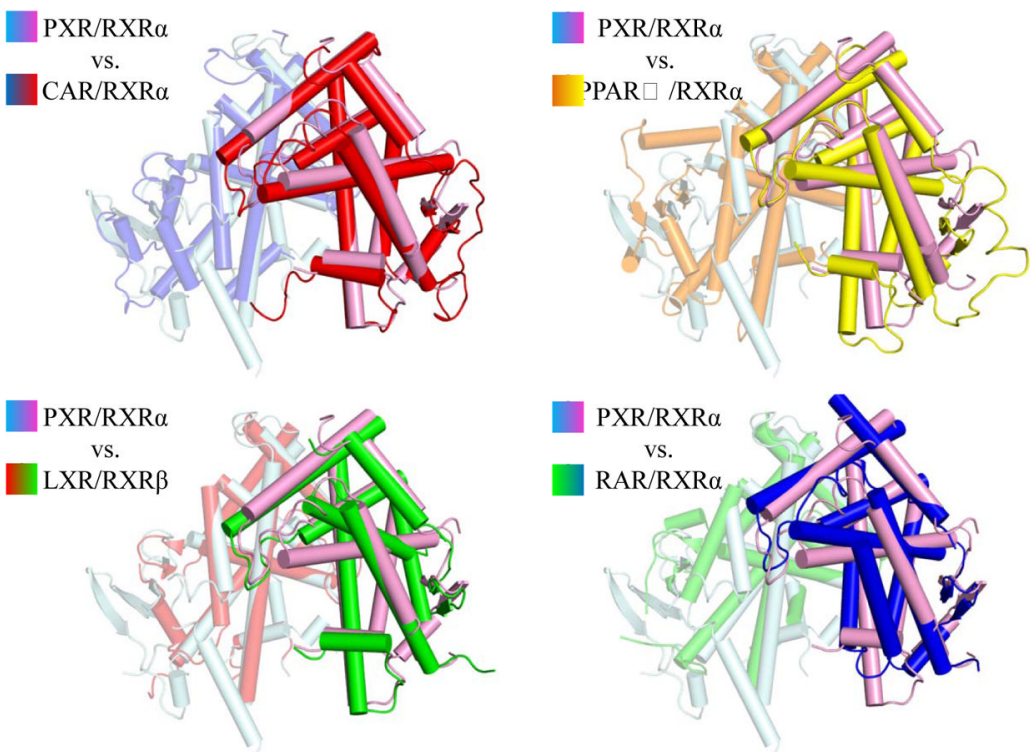

Figure 3. Comparison of RXRa Heterodimers

The LBD of PXR was superimposed on those of CAR, PPAR $\gamma$, LXR and RAR, and the positions of the RXRa LBD in these heterodimers are shown and colored as indicated. 

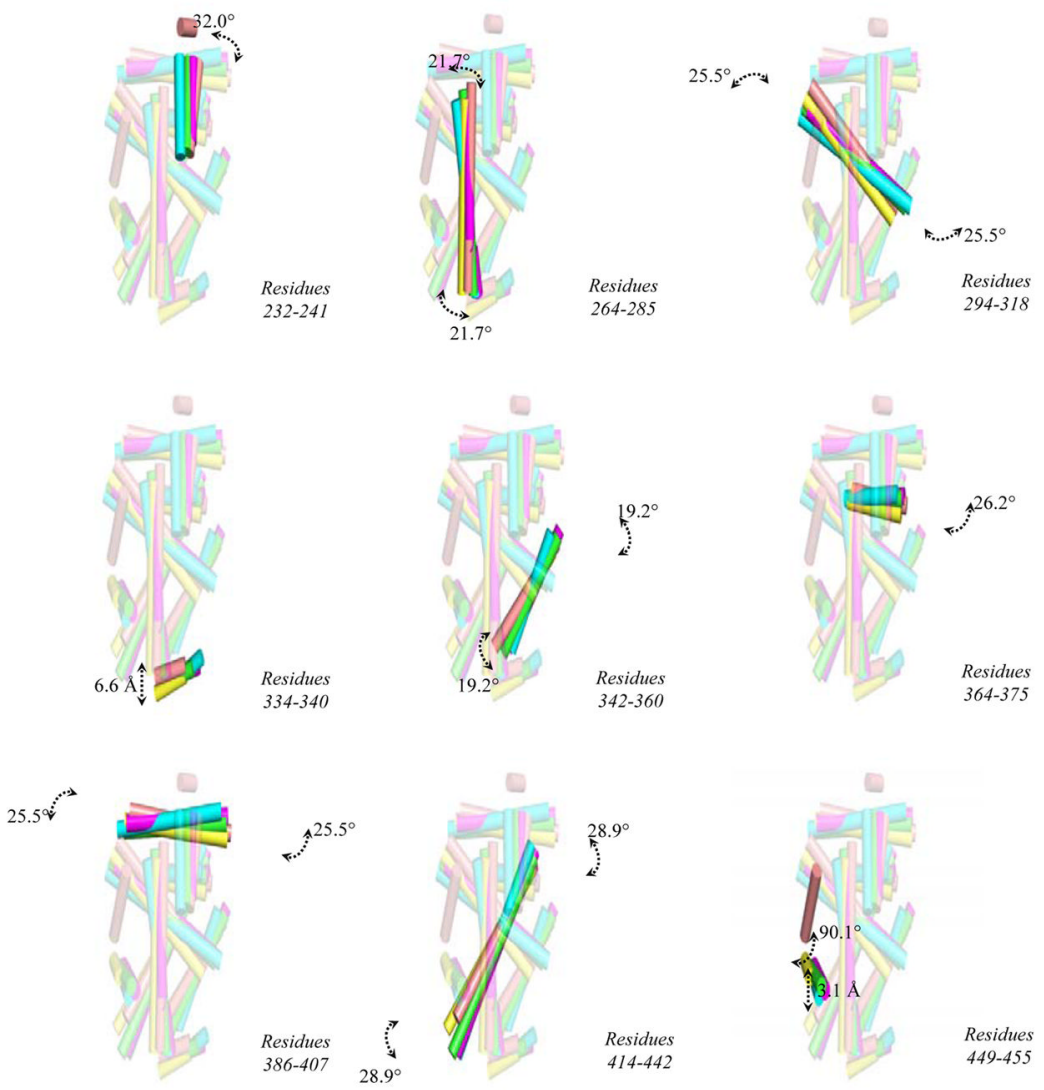

Figure 4. RXRa Positional Shifts

Specific structural translations (indicated in $\AA$ ) or rotations (in ${ }^{\circ}$ ) for secondary structural elements of the RXRa LBD from heterodimer complexes with PXR, CAR, PPAR $\gamma$, LXR and RAR when the non- RXRa LBDs are superimposed (e.g., Fig. 3). Viewed rotated roughly $30^{\circ}$ about the vertical axis relative to Figure 3 . 

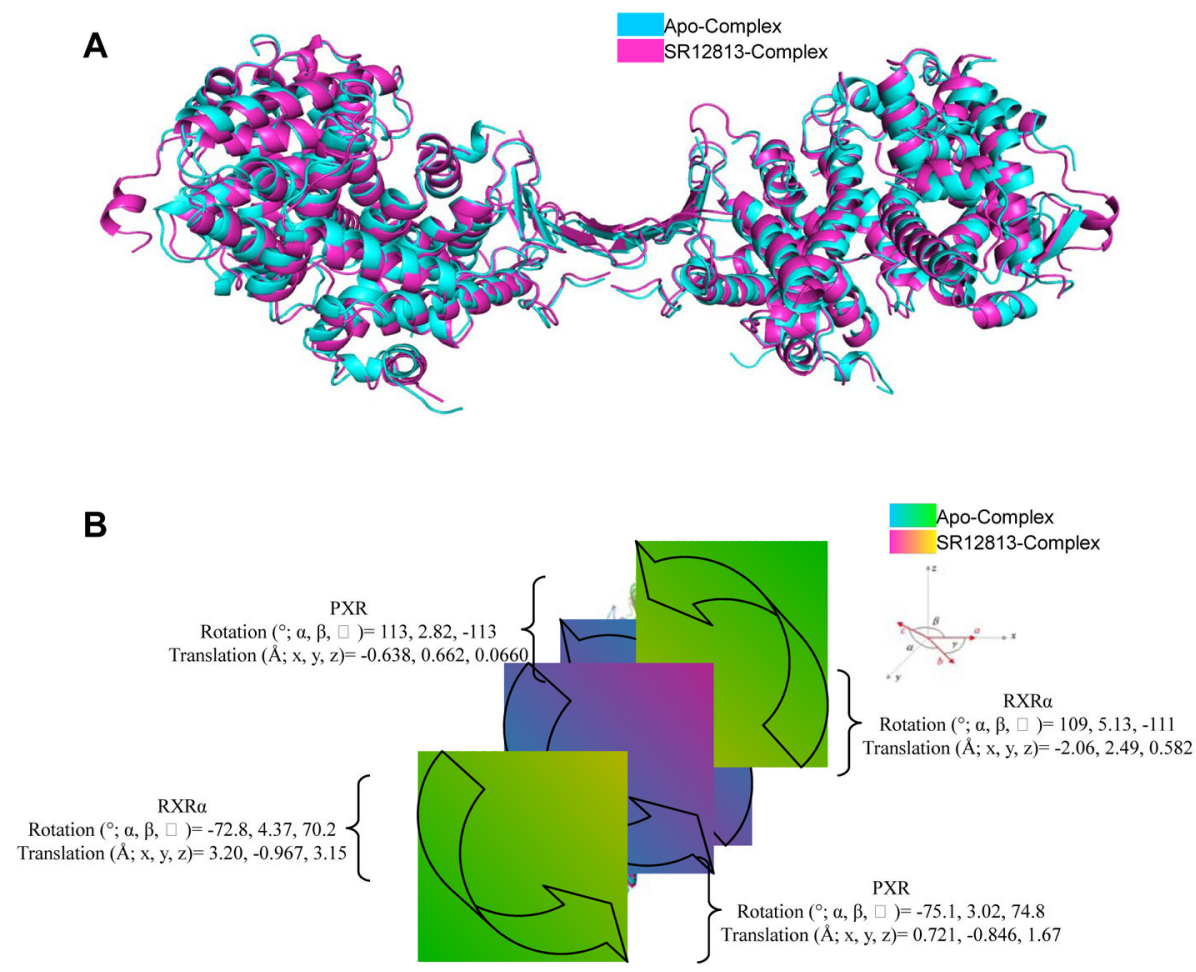

Figure 5. Comparison of the Apo and SR12813 Bound PXR-RXR Complexes

A. Superposition of the unliganded ${ }^{30}$ human PXR homodimer from the PXR-RXRa LBD complex (cyan) with the structure of the human PXR homodimer from the PXR-RXRa LBD complex in which PXR contains bound SR12813 (magenta) (viewed 90 degrees rotated about the vertical relative to Figure 1A). B. Rotational and translational shifts in position between of the PXR LBDs (cyan, magenta) and the RXRa LBDs (green, yellow) in the apo and SR12813-bound PXR complexes. 


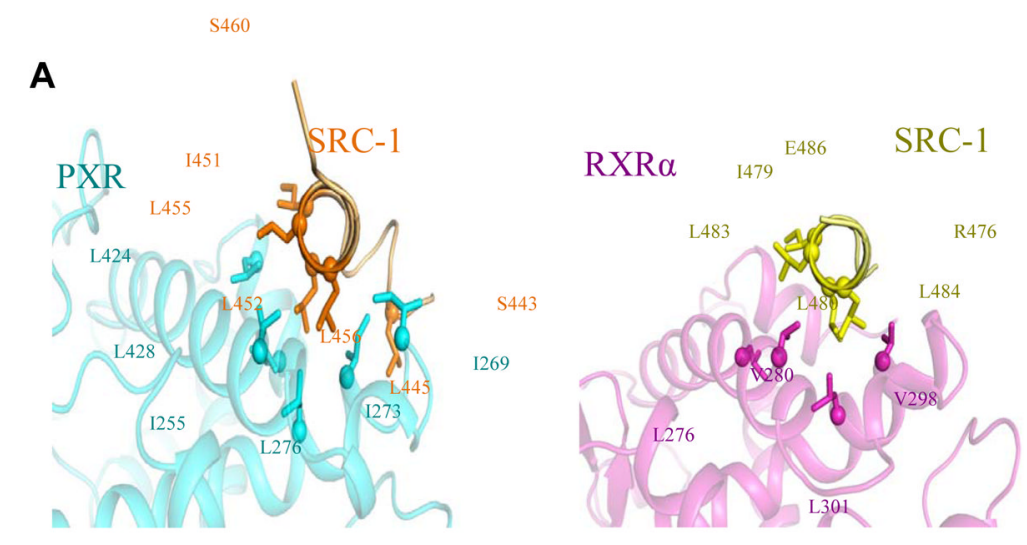

B

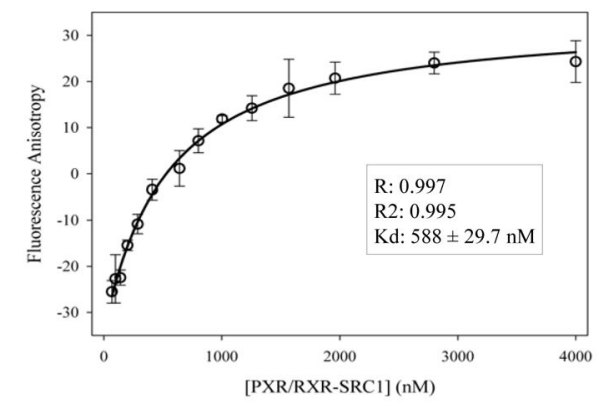

Figure 6. SRC-1-LBD Binding Interfaces

A. Ordered regions of the transcriptional coactivators SRC-1 (orange, yellow) observed in contact with the LBDs of PXR (cyan) and RXRa (magenta). Note that the SRC-1 peptides were fused using a glycine-serine linker to the C-termini of each LBD, and are thus labeled with the corresponding residues within each construct (see Methods). The following region of human steroid receptor coactivator-1 (SRC-1): 678-

SSHSSLTERHKILHRLLQEGSPS-700, with the LxxLL motif in bold, was linked to each receptor. In PXR, the region corresponding to 681-698 of hSRC-1 is ordered, and is numbered 443-460; in RXRa, the region corresponding to 686-696 of hSRC-1 is ordered, and is numbered 476-486 B. Binding curve of SRC-1 peptide binding (residues 676-700) to the PXR LBD, measured by fluorescence anisotropy. In this example, the LBD complex consists of the unbound and unfused version of the PXR LBD and the SRC-1-fused RXRa LBD. This creates a scenario that allows for free SRC-1 peptide to bind only the LxxLL motif in PXR. 
A

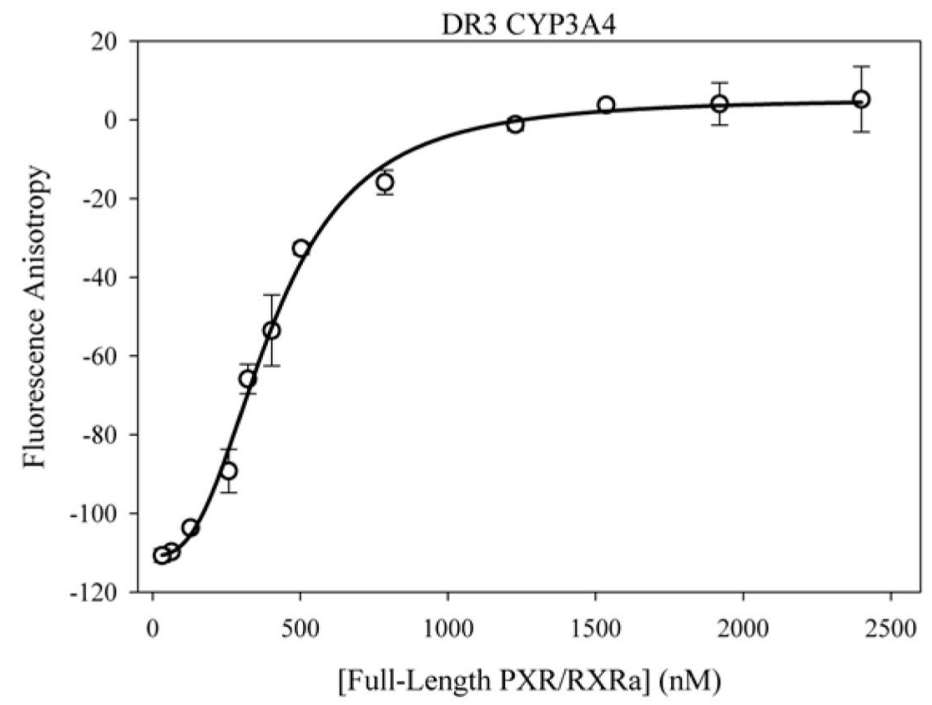

B

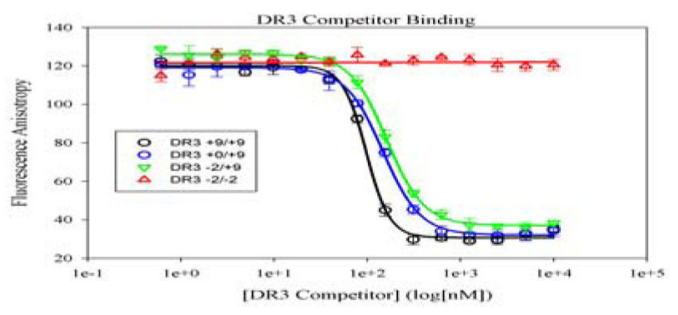

Figure 7. DNA Binding by PXR-RXRa

A. Binding measured by fluorescence anisotropy of the complex of full-length PXR with full-length RXRa to a FAM-labeled 15-bp DNA duplex composed of a DR3 motif from the promoter of the human CYP3A4 gene product (see Tables 3, 4). B. Competition binding experiments using fluorescence anisotropy and monitoring the dissociation of the FAM-DR3 DNA duplex by increasing concentrations of unlabeled duplexes (see Tables 3, 4). 
A

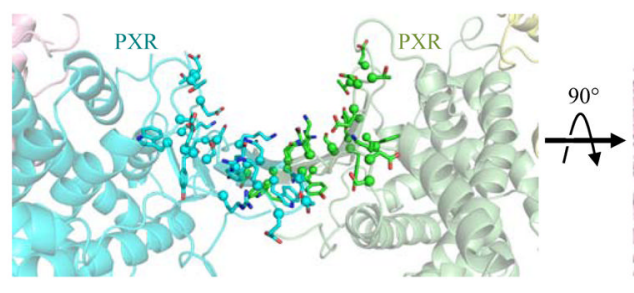

B

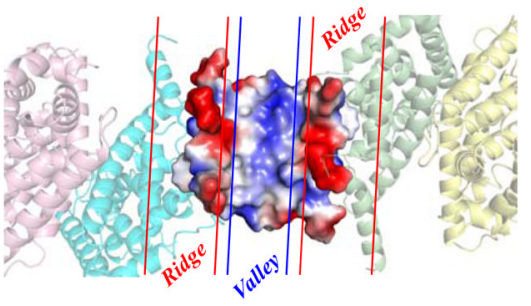

Figure 8. Surface of the PXR Homodimer

A. Ribbon representation of the homodimer of the human PXR LBDs in the PXR-RXRa heterotetramer complex reported here, with surface exposed residue shown as sticks (viewed in the same orientation as Figure 3A). B. Electrostatic surface of the homodimer interface shown in panel A, with the regions of positive (blue) and negative (red) charge indicated. 
Table 1

Crystallographic Statistics

\begin{tabular}{|c|c|c|}
\hline \multicolumn{3}{|c|}{ Data Collection } \\
\hline & Apo-PXR/RXR LBD Complex & SR12813-bound PXR/RXR LBD Complex \\
\hline X-ray source & \multicolumn{2}{|c|}{ APS GM/CA-CAT 23-ID } \\
\hline Space group & $P 2_{1} 2_{1} 2_{1}$ & $P 2_{1}{ }_{2}{ }_{2}{ }_{1}$ \\
\hline Unit cell: $a, b, c(\AA) ; a=\beta=\gamma=90^{\circ}$ & $70.26,109.6,169.9$ & $70.09,120.3,175.8$ \\
\hline Resolution $(\AA)$ (highest shell) & $50.0-2.77(2.84-2.77)$ & $50.0-2.80(2.85-2.80)$ \\
\hline $\mathrm{I} / \sigma$ & $4.70(1.76)$ & $6.68(2.34)$ \\
\hline $\mathrm{R}_{\text {sym }}$ (highest shell) & $0.132(0.321)$ & $0.144(0.440)$ \\
\hline Completeness (\%) & $96.1(86.8)$ & 99.4 (98.7) \\
\hline Redundancy & $3.6(2.4)$ & $3.9(2.0)$ \\
\hline \multicolumn{3}{|c|}{ Refinement } \\
\hline Resolution $(\AA)$ (highest shell) & $50.0-2.80(2.85-2.80)$ & $50.0-2.80(2.85-2.80)$ \\
\hline No. of unique reflections & 31748 & 37160 \\
\hline $\mathrm{R}_{\mathrm{work}}$ & $0.250(0.310)$ & $0.245(0.315)$ \\
\hline $\mathrm{R}_{\text {free }}$ & $0.298(0.300)$ & $0.298(0.345)$ \\
\hline Molecules/asymmetric unit (AU) & 2 PXR; 2 RXRa & 2 PXR; 2 RXRa \\
\hline No. of amino acids per AU & 1044 & 1063 \\
\hline No. of waters per AU & 175 & 160 \\
\hline Average $B$-factors & 35.4 & 54.3 \\
\hline Macrolmolecule & 35.5 & 54.3 \\
\hline Solvent & 29.4 & 47.2 \\
\hline \multicolumn{3}{|l|}{ R.M.S. deviations } \\
\hline Bond lengths $(\AA)$ & 0.004 & 0.005 \\
\hline Bond angles $\left({ }^{\circ}\right)$ & 0.880 & 1.00 \\
\hline \multicolumn{3}{|l|}{ Ramachandran (\%) } \\
\hline Favored/Allowed & 99.3 & 99.2 \\
\hline Outliers & 0.69 & 0.77 \\
\hline
\end{tabular}


Table 2

Peptide Binding by Fluorescence Anisotropy

\begin{tabular}{|c|c|c|}
\hline & \multicolumn{2}{|c|}{ SRC1 Peptide Binding } \\
\hline LBD(s) Employed & $\mathbf{K}_{\mathbf{d}}(\mathbf{n M})$ & p-values \\
\hline $\mathrm{RXRa}$ & $1560 \mathrm{nM} \pm 198^{*}$ & $* 0.005$ \\
\hline $\mathrm{RXRa} / \mathrm{PXR}-\mathrm{SRC1}$ & $778 \mathrm{nM} \pm 88.8^{*},^{\wedge}$ & \\
\hline $\mathrm{PXR}$ & $1180 \mathrm{nM} \pm 92.2^{\#}$ & ${ }^{\wedge} 0.01$ \\
\hline $\mathrm{PXR/RXRa}-\mathrm{SRC} 1$ & $588 \mathrm{nM} \pm 29.7^{\#, \wedge}$ & ${ }^{*} 0.009$ \\
\hline
\end{tabular}


Table 3

DNA Oligonucleotides Examined

\begin{tabular}{|c|c|c|}
\hline Element Type & DNA Sequence & Abbreviation \\
\hline \multirow{13}{*}{ DR3 (CYP3A4) } & $\begin{array}{l}5^{\prime} \text {-FAM-TGAACTTGCTGACCC-3' } \\
3^{\prime} \text {-ACTTGAACGACTGGG-5' }\end{array}$ & DR3 FAM \\
\hline & 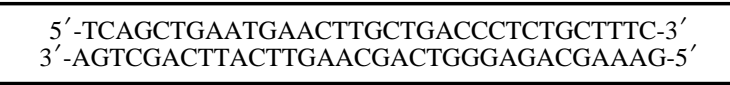 & DR3 +9/+9 \\
\hline & $\begin{array}{c}\text { 5'-GCTGAATGAACTTGCTGACCCTCTGCTTTC-3' }^{\prime} \\
\text { 3'-CGACTTACTTGAACGACTGGGAGACGAAAG-5' }\end{array}$ & $\mathrm{DR} 3+6 /+9$ \\
\hline & $\begin{array}{c}\text { 5'-GAATGAACTTGCTGACCCTCTGCTTTC-3' }^{\prime} \\
3^{\prime} \text {-CTTACTTGAACGACTGGGAGACGAAAG-5' }\end{array}$ & $\mathrm{DR} 3+3 /+9$ \\
\hline & $\begin{array}{c}5^{\prime} \text {-TGAACTTGCTGACCCTCTGCTTTC-3' } \\
3^{\prime} \text {-ACTTGAACGACTGGGAGACGAAAG-5' }\end{array}$ & $\mathrm{DR} 3+0 /+9$ \\
\hline & $\begin{array}{c}\text { 5'-TCAGCTGAATGAACTTGCTGACCCTCTGCT-3' } \\
\text { 3'-AGTCGACTTACTTGAACGACTGGGAGACGA-5' }^{\prime} \text { ' }\end{array}$ & $\mathrm{DR} 3+9 /+6$ \\
\hline & $\begin{array}{l}5^{\prime} \text {-TCAGCTGAATGAACTTGCTGACCCTCT-3' } \\
3^{\prime} \text {-AGTCGACTTACTTGAACGACTGGGAGA-5' }\end{array}$ & DR $3+9 /+3$ \\
\hline & $\begin{array}{l}5^{\prime} \text {-TCAGCTGAATGAACTTGCTGACCC-3' } \\
3^{\prime} \text {-AGTCGACTTACTTGAACGACTGGG-5' }\end{array}$ & $\mathrm{DR} 3+9 /+0$ \\
\hline & $\begin{array}{c}\text { 5'-GCTGAATGAACTTGCTGACCCTCTGCT-3' }^{\prime} \\
3^{\prime} \text {-CGACTTACTTGAACGACTGGGAGACGA-5' }\end{array}$ & DR $3+6 /+6$ \\
\hline & $\begin{array}{l}\text { 5'-GAATGAACTTGCTGACCCTCT-3' }^{\prime} \\
3^{\prime} \text {-CTTACTTGAACGACTGGGAGA-5' }\end{array}$ & $\mathrm{DR} 3+3 /+3$ \\
\hline & $\begin{array}{c}\text { 5'-AACTTGCTGACCCTCTGCTTTC-3' } \\
\text { 3'-TTGAACGACTGGGAGACGAAAG-5' }^{\prime} \text { - }\end{array}$ & DR3 $-2 /+9$ \\
\hline & $\begin{array}{l}\text { 5',-TCAGCTGAATGAACTTGCTGAC-3' } \\
3^{\prime} \text {-AGTCGACTTACTTGAACGACTG-5' }\end{array}$ & $\mathrm{DR} 3+9 /-2$ \\
\hline & $\begin{array}{l}5^{\prime} \text {-AACTTGCTGAC-3' } \\
3^{\prime} \text {-TTGAACGACTG-5' }\end{array}$ & DR3 $-2 /-2$ \\
\hline \multirow{11}{*}{ ER6 (CYP3A4) } & $\begin{array}{c}5^{\prime} \text {-FAM-TGAACTCAAAGGAGGTCA-3' } \\
3^{\prime} \text {-ACTTGAGTTTCCTCCAGT-5' }\end{array}$ & ER6 FAM \\
\hline & $\begin{array}{c}5^{\prime} \text {-CATAGAATATGAACTCAAAGGAGGTCAGTGAGTGGT-3' } \\
3^{\prime} \text {-GTATCTTATACTTGAGTTTCCTCCAGTCACTCACCA-5' }\end{array}$ & ER6 +9/+9 \\
\hline & $\begin{array}{c}5^{\prime} \text {-AGAATATGAACTCAAAGGAGGTCAGTGAGTGGT-3' } \\
3^{\prime} \text {-TCTTATACTTGAGTTTCCTCCAGTCACTCACCA-5' }\end{array}$ & ER6 +6/+9 \\
\hline & $\begin{array}{l}\text { 5'-ATATGAACTCAAAGGAGGTCAGTGAGTGGT-3' }^{\prime} \\
\text { 3'-TATACTTGAGTTTCCTCCAGTCACTCACCA-5' }\end{array}$ & ER6 +3/+9 \\
\hline & $\begin{array}{l}\text { 5'-TGAACTCAAAGGAGGTCAGTGAGTGGT-3' } \\
3^{\prime} \text {-ACTTGAGTTTCCTCCAGTCACTCACCA-5' }\end{array}$ & ER6 +0/+9 \\
\hline & $\begin{array}{c}\text { 5'-CATAGAATATGAACTCAAAGGAGGTCAGTGAGT-3' }^{\prime} \\
3^{\prime} \text {-GTATCTTATACTTGAGTTTCCTCCAGTCACTCA-5' }\end{array}$ & ER6 +9/+6 \\
\hline & $\begin{array}{c}\text { 5'-CATAGAATATGAACTCAAAGGAGGTCAGTG-3' } \\
\text { 3'-GTATCTTATACTTGAGTTTCCTCCAGTCAC-5' }\end{array}$ & ER6 +9/+3 \\
\hline & $\begin{array}{l}\text { 5'-CATAGAATATGAACTCAAAGGAGGTCA-3' }^{\prime} \\
3^{\prime} \text {-GTATCTTATACTTGAGTTTCCTCCAGT-5' }\end{array}$ & ER6 +9/+0 \\
\hline & $\begin{array}{c}5^{\prime} \text {-AGAATATGAACTCAAAGGAGGTCAGTGAGT-3' } \\
\text { 3'-TCTTATACTTGAGTTTCCTCCAGTCACTCA-5' }^{\prime}\end{array}$ & ER6 +6/+6 \\
\hline & $\begin{array}{l}5^{\prime} \text {-ATATGAACTCAAAGGAGGTCAGTG-3' } \\
3^{\prime} \text {-TATACTTGAGTTCCTCCAGTCAC-5' }\end{array}$ & ER6 +3/+3 \\
\hline & $\begin{array}{l}5^{\prime} \text {-AACTCAAAGGAGGTCAGTGAGTGGT-3' } \\
3^{\prime} \text {-TTGAGTTCCTCCAGTCACTCACCA-5' }\end{array}$ & ER6 -2/+9 \\
\hline
\end{tabular}




\begin{tabular}{|c|c|c|}
\hline Element Type & DNA Sequence & Abbreviation \\
\hline & $\begin{array}{l}5^{\prime} \text {-CATAGAATATGAACTCAAAGGAGGT-3' } \\
3^{\prime} \text {-GTATCTTATACTTGAGTTCCTCCA-5' }\end{array}$ & ER6 +9/-2 \\
\hline & $\begin{array}{l}\text { 5' }^{\prime} \text {-AACTCAAAGGAGGT-3' } \\
3^{\prime} \text {-TTGAGTTTCCTCCA-5' }\end{array}$ & ER6 -2/-2 \\
\hline
\end{tabular}


Table 4

DNA Binding by Fluorescence Anisotropy

\begin{tabular}{|c|c|c|c|c|}
\hline DR3 Direct Binding & $\mathbf{K}_{\mathbf{d}}(\mathbf{n M})$ & $\mathbf{E R 6}$ Direct Binding & $\mathbf{K}_{\mathbf{d}}(\mathbf{n M})$ & \multirow{2}{*}{} \\
\cline { 1 - 4 } DR3 FAM & $\mathbf{2 0 6} \pm \mathbf{5 3}$ & ER6 FAM & $\mathbf{2 1 5} \pm \mathbf{3 6}$ & \\
\hline DR3 Competitors & $\mathbf{K}_{\mathbf{i}}(\mathbf{n M})$ & ER6 Competitors & $\mathbf{K}_{\mathbf{i}}(\mathbf{n M})$ & \multirow{2}{*}{ p-value } \\
\hline DR3 +9/+9 & $86.5 \pm 4.5$ & ER6 +9/+9 & $94.8 \pm 4.8$ & 0.150 \\
\hline DR3 +6/+9 & $94.4 \pm 4.0$ & ER6 +6/+9 & $98.1 \pm 4.7$ & 0.149 \\
\hline DR3 +3/+9 & $87.2 \pm 4.5$ & ER6 +3/+9 & $103 \pm 5.1$ & \multirow{2}{*}{$0.038^{*}$} \\
\hline DR3 +0/+9 & $131 \pm 6.6$ & ER6 +0/+9 & $113 \pm 6.2$ & 0.098 \\
\hline DR3 +9/+6 & $88.3 \pm 4.2$ & ER6 +9/+6 & $96.6 \pm 4.6$ & 0.159 \\
\hline DR3 +9/+3 & $82.8 \pm 3.6$ & ER6 +9/+3 & $104 \pm 4.7$ & $0.013^{*}$ \\
\hline DR3 +9/+0 & $95.6 \pm 4.7$ & ER6 +9/+0 & $98.4 \pm 4.8$ & 0.282 \\
\hline DR3 +6/+6 & $98.0 \pm 4.9$ & ER6 +6/+6 & $120 \pm 5.5$ & $0.028^{*}$ \\
\hline DR3 +3/+3 & $95.6 \pm 5.1$ & ER6 +3/+3 & $131 \pm 5.8$ & $0.002^{*}$ \\
\hline DR3 -2/+9 & $144 \pm 6.0$ & ER6 -2/+9 & $155 \pm 7.0$ & 0.317 \\
\hline DR3 +9/-2 & $102 \pm 5.2$ & ER6 +9/-2 & $146 \pm 7.2$ & $0.024^{*}$ \\
\hline DR3 -2/-2 & N.C. & ER6 -2/-2 & N.C. & - \\
\hline
\end{tabular}

Statistically significant $(\mathrm{p}<0.05)$; N.C. - not a competitor 